\title{
Inhibition of Cholecystokinin Response in the Gallbladder by Dibenamine and Its Protection by Benzodiazepines
}

\author{
Kazuhiko KUBOTA, Kiminobu SUGAYA, Fumio FUJII, \\ Masahiro ITONAGA and Nobuyoshi SUNAGANE \\ Department of Pharmacology. Faculty of Pharmaccutical Sciences. \\ Science University of Tokyo. Ichigava Funagawara-machi, Shinjuku-ku, Tokyo 162, Japan
}

Accepled July 20, 1985

\begin{abstract}
The contractile response of the guinea-pig gallbladder to cholecystokinin (CCK) and acetylcholine (ACh) was irreversibly inhibited by $5 \times 10^{-5} \mathrm{M}$ dibenamine, and the dibenamine-induced inhibition in the CCK response was prevented by $10^{-4} \mathrm{M}$ chlordiazepoxide (CDP) and diazepam (DZP), but not by $10^{-2} \mathrm{M}$ proglumide or $10^{6} \mathrm{M}$ atropine. The dibenamine-induced inhibition in the ACh response was prevented by $10^{-6} \mathrm{M}$ atropine, but not by $10^{-4} \mathrm{M}$ CDP. These findings suggest that the binding of CCK to the CCK receptor can be inhibited by benzodiazepines.
\end{abstract}

Several CCK antagonists have been hitherto reported $(1-3)$, and proglumide has been the most widely used as a selective antagonist against CCK. However, the potency of proglumide as a CCK antagonist is rather low. In our previous paper (4), it was shown that benzodiazepines like CDP and DZP antagonized cholecystokinin action to contract the guinea-pig gallbladder muscle in a competitive manner, and the potency of the benzodiazepines on the antagonism was much higher than that of proglumide.

In our other papers $(5,6)$ ), it was also demonstrated that the antinociceptive and satiety action of octapeptide cholecystokinin (CCK8) which was administered intracisternally to mice was significantly antagonized by very low intraperitoneal doses of benzodiazepines.

In this paper, authors intended to provide further evidence that benzodiazepines act on CCK receptors.

Male guinea pigs weighing 350 to $400 \mathrm{~g}$ were stunned by a blow on the head, and the gallbladder was excised. The gallbladder was cut helically, and strips about $10 \mathrm{~mm}$ long and $4 \mathrm{~mm}$ wide were prepared. The strips were suspended in Locke-Ringer solution which was maintained at $32^{\circ} \mathrm{C}$ and bubbled with air. The Locke-Ringer solution had the following composition (mM): $\mathrm{NaCl}, 154.0$; $\mathrm{KCl}, 5.6 ; \mathrm{CaCl}_{2}, 2.2 ; \mathrm{MgCl}_{2}, 2.1: \mathrm{NaHCO}_{3}$. 5.9: and glucose, 2.8. The muscle strips were connected via surgical silk to a force displacement transducer for monitoring changes in isometric force. The muscle strips were equilibrated for $30 \mathrm{~min}$ in the Locke-Ringer solution and then applied repeatedly with agonists, $10^{-8} \mathrm{M} \mathrm{CCK} 8$ and $10^{-4} \mathrm{M} \mathrm{ACh}$, until the contractile response to the agonists became constant. The strips were exposed to $5 \times 10^{-5} \mathrm{M}$ dibenamine sequentially twice for $30 \mathrm{~min}$ each, washed with Locke-Ringer solution for $90 \mathrm{~min}$ and applied with an agonist. The contractile responses of the muscle strips to an agonist before and after the exposure to dibenamine were compared. For the purpose of protecting receptors, antagonists such as atropine, benzodiazepine and proglumide were applied to the muscle strips for $15 \mathrm{~min}$ prior to the dibenamine treatment and during the dibenamine treatment.

CDP hydrochloride and DZP were provided from Yamanouchi Pharmaceutical Co. Ltd. (Tokyo) and proglumide from Eisai Co., Ltd. (Tokyo). Dibenamine hydrochloride was purchased from Tokyo-Kasei Co. (Tokyo) and CCK8 from Protein Research Foundation (Osaka). 
Significant differences between data were assessed by Student's t-test for paired samples.

The contractile response of the gallbladder muscle to CCK8 was significantly depressed by $60 \mathrm{~min}$ exposure of the muscle to $5 \times 10^{-5}$ $M$ of dibenamine, and the depression of the response by dibenamine was significantly prevented in the presence of $10^{-4} \mathrm{M}$ CDP and DZP, but not prevented by $10^{-6} \mathrm{M}$ atropine and $10^{-2} \mathrm{M}$ proglumide. On the other hand, the inhibition of the contractile response of the gallbladder to ACh by dibenamine exposure was significantly prevented by $10^{-6} \mathrm{M}$ atropine but not by $10^{-4} \mathrm{M} \mathrm{CDP}$ (Table 1).

In our present experiments, $10^{-8} \mathrm{M} \mathrm{CCK} 8$ was used, since this concentration of CCK 8 was close to the ED50 in the CCK8 response of the gallbladder. The contractile response of the gallbladder to $10^{-8} \mathrm{M} \mathrm{CCK8}$ was significantly $(P<0.05)$ inhibited to $56.5 \pm$ $5.3 \%$ by application of $10^{-5} \mathrm{M}$ dibenamine and more significantly $(P<0.01)$ to $39.6 \pm$ $1.7 \%$ by $10^{-4} \mathrm{M}$ dibenamine. Therefore, we used $5 \times 10^{-5} \mathrm{M}$ dibenamine in the present receptor protection experiments (Table 2 ).

Dibenamine has been widely used as an irreversible alkylating agent for $\mathrm{ACh}(7,8)$. histamine $(8,9)$ and $\alpha$-adrenergic receptors $(8,10,11)$. In the present work, it was demonstrated that the CCK receptor of the guinea-pig gallbladder muscle was also irreversibly inhibited by dibenamine, and the inhibition was significantly protected in the presence of $10^{-4} \mathrm{M} \mathrm{CDP}$ and DZP. In the previous paper, authors demonstrated that CDP and DZP caused significant rightward parallel shift of the dose-response curve for CCK when they were present in concentrations of $10^{-5} \mathrm{M}$ to $10^{-6} \mathrm{M}$, and Schild analysis of the parallel shift of the CCK

Table 1. Effect of chlordiazepoxide and atropine on the dibenamine $\left(5 \times 10^{-5} \mathrm{M}\right)$-induced inhibition of the contractile response of guinea-pig gallbladder to $\mathrm{ACh}\left(10^{-4} \mathrm{M}\right)$

\begin{tabular}{ll}
\hline \multicolumn{1}{c}{ Treatment } & Contractile response (\%) \\
Dibenamine (control) & $23.33 \pm 2.82$ \\
Dibenamine -Chlordiazepoxide $\left(10^{-4} \mathrm{M}\right)$ & $20.38 \pm 2.05$ \\
Dibenamine (control) & $28.84 \pm 2.40$ \\
Dibenamine-Atropine $\left(10^{-6} \mathrm{M}\right)$ & $50.75 \pm 2.60^{* *}$ \\
\hline
\end{tabular}

The contractile response of the gallbladder to ACh before dibenamine treatment was taken as $100 \%$. The values are given as the mean \pm S.E. $(n=6)$. Significant difference from the control at ${ }^{* *} P<0.01$.

Table 2. Effect of chlordiazepoxide, diazepam, proglumide and atropine on the dibenamine $\left(5 \times 10^{-5}\right.$ $\mathrm{M})$-induced inhibition of the contractile response of guinea-pig gallbladder to CCK $8\left(10^{-8} \mathrm{M}\right)$

\begin{tabular}{lc} 
Treatment & Contractle response (\%) \\
\hline Dibenamine (control) $(6)$ & $64.11 \pm 2.35$ \\
Dibenamine-Chlordiazepoxide $\left(10^{-4} \mathrm{M}\right)(6)$ & $76.07 \pm 2.30^{* *}$ \\
Dibenamine (control) $(12)$ & $48.08 \pm 3.56$ \\
Dibenamine+Diazepam $\left(10^{-5} \mathrm{M}\right)(6)$ & $62.76 \pm 8.59$ \\
Dibenamine-Diazepam $\left(10^{-4} \mathrm{M}\right)(6)$ & $70.28 \pm 3.45^{* *}$ \\
Dibenamine (control) $(12)$ & $55.47 \pm 2.92$ \\
Dibenamine+Proglumide $\left(10^{-3} \mathrm{M}\right)(6)$ & $56.85 \pm 3.26$ \\
Dibenamine+Proglumide $\left(10^{-2} \mathrm{M}\right)(6)$ & $58.27 \pm 1.32$ \\
Dibenamine (control) $(6)$ & $60.04 \pm 4.64$ \\
Dibenamine+Atropine $\left(10^{-6} \mathrm{M}\right)(6)$ & $58.52 \pm 2.57$ \\
\hline
\end{tabular}

"The contractile response of the gallbladder to CCK8 before dibenamine treatment was taken as $100 \%$. The numbers of experiments are in parentheses. The values are given as the mean $\pm S$. E. Significant difference from the contral at ${ }^{*} \mathrm{P}<0.01$. 
dose-response curve supported the compe titive antagonism between benzodiazepines and CCK (4). The present results provide further evidence that benzodiazepines can bind to CCK receptors and selectively protect it from inhibition by dibenamine, since crossprotection of $\mathrm{ACh}$ and $\mathrm{CCK}$ receptors by benzodiazepines and atropine was not observed. Proglumide has been claimed to be a selective receptor antagonist (3) of CCK. In the present protection experiments, proglumide considerably prevented the decrease in the CCK response produced by dibenamine, but the prevention was not statistically significant. According to our calculation (4), the $\mathrm{pA}_{2}$ value for proglumide which was obtained on the basis of $K_{k}$ reported by Kaplita and Roebuch (2) was 3.82. By comparison of this $\mathrm{pA}_{2}$ value with 7.33 for DZP and 6.70 for CDP (4), the activity of proglumide on CCK antagonism is estimated to be about one thousand times lower than those of DZP and CDP. Concentrations of proglumide higher than $10^{-2} \mathrm{M}$ could not be used in the present experiments because of its solubility. The present results, therefore, demonstrated that proglumide was a very weak antagonist of CCK, giving further support to the previously reported (46) antagonism between CCK8 and benzodiazepines.

Acknowledgements: The authors wish to thank Yamanouchi Pharmaceutical Co., Ltd and Eisai Co. Ltd. for kindly providing us with the benzodiazepines and proglumide.

\section{References}

1 Hutchison, J.B. and Dockray, D.J.: Inhibition of the action of cholecystokinin octapeptide on the guinea pig ileum myenteric plexus by dibutyryl cyclic guanosine monophosphate. Brain Res. 202, $501(1980)$
2 Kaplita, P.V. and Roebuck, B.D.: Proglumide antagonizes the stimulation of rabit gallbladder by cholecystokinin. Arch. Int. Pharmacodyn. Ther. 269, 271 (1984)

3 Gardner, J.D. and Jensen, R.T.: Cholecystokinin receptor antagonist. Am. J. Physiol, 9, G471G476 (1984)

4 Kubota, K., Sugaya, K., Sunagane, N., Matsuda, I. and Uruno, T.: Cholecystokinin antagonism by benzodiazepines in the contractile response of the isolated guinea-pig gallbladder. Eur. J. Pharmacol. 110, 225-231 (1985)

5 Kubota, K., Sugaya, K., Matsuda, I., Matsuoka, $Y$. and Terawaki, Y.: Reversal of antinociceptive effect of cholecystokinin by benzodiazepines and a benzodiazepine antagonist, Ro 15-1788. Japan. J. Pharmacol. 37, 101-105 (1985)

6 Kubota, K., Matsuda, I., Sugaya, K. and Uruno, T.: Cholecystokinin antagonism by benzodiazepines in the food intake in mice. Physiol. Behav. (1985) (in press)

7 Araki, H. and Matsumoto, H.: Mode of antagonism of dibenamine against the acetylcholineinduced contraction of excised ileum from the rabbit. Japan. J. Phamacol. 24, Supp. 147 (1974)

8 Furchgott, R.F.: Dibenamine blockade in strips of rabbit aorta and its use in differentiating receptors. J. Pharmacol. Exp. Ther. 111, 265-284 (1954)

9 Uchida, M. and Takagi, K.: Purification of histamine receptor. (11) Subcellular distribution of specifically bound dibenamine. Japan. J. Pharmacol. 23, 337-347 (1973)

10 Swamy, V.C. and Triggle, D.J.: 2-Halogenoethylamines and the role of $\mathrm{Ca}^{2+}$ in adrenergic $\alpha$-receptor activation in the rat vas deferens. Eur. J. Pharmacol. 19, 67-78 (1972)

11 Tuttle, R.R. and Moran, N.C.: The effect of calcium depletion on the combination of agonists and competitive antagonists with alpha adrenergic and histaminergic receptors of rabbit aorta. J. Pharmacol. Exp. Ther. 169, 255-263 (1969) 